\title{
State Support of the Real Sector of the Economy: Legal Regulation
}

\author{
A. V. Fadeev ${ }^{(\bowtie)}$ \\ Samara State University of Economics, Samara, Russia \\ Alexfadl960@mail.ru
}

\begin{abstract}
The problem of state support for business is the most important in today's conditions. The cataclysms that have occurred recently have affected the world economy. The world has ceased to be balanced. Business froze in fear of inevitable bankruptcy, unemployment and ruin. Political changes in Russia, which began in January 2020, the drop in oil prices, the collapse of the ruble, which followed the relative stability of the Russian national currency and reached the pandemic country, negatively affected business in the country. The development of urgent state measures to support small and medium-sized enterprises is the only way to maintain its viability. These measures should be based on a clear regulatory framework that does not allow vague interpretations and legal incidents. Using the comparative legal method, it is necessary to draw the experience of those countries in which there is a state policy in relation to small and medium-sized businesses, which is a system of socio-economic actions built on the principle of ensuring the favorable development of this sector of the economy and to develop measures that can preserve it in conditions of prevailing force majeure. The aim of this work is a comparative analysis of measures taken by the world community and Russia to support small and medium-sized businesses during the economic crisis caused by Covid19. Particular attention is paid to the legislative justification of measures taken in Russia and the identification of shortcomings of the newly adopted normative legal acts.
\end{abstract}

Keywords: Economic crisis $\cdot$ Government support $\cdot$ Pandemic $\cdot$ Small and medium business

\section{Introduction}

The economy of any modern state is divided into two interconnected sectors - financial and real. The financial sector deals with monetary relations and through the banking system, with its credit, financial and exchange instruments, has an impact on the demand and supply of goods and services. The real sector of the economy is engaged in their production. The real sector of the economy is engaged in the production of tangible and intangible products, since, along with industry and agriculture, it includes scientific enterprises and trade organizations. In each country, the real sector of the economy has its own specifics, which is formed on the basis of various factors - the geopolitical location of the state, the possession of natural resources and minerals, climatic conditions, etc. 
Almost all states, even with very developed economy, subsidize certain sectors of the real sector of the economy in different ways to maintain economic balance, regulate supply and demand, and set prices for goods and services. This need exists in industry and agriculture, which often due to low labor productivity and technological backwardness feel the need for financial support from the state. With an increase in government spending to support small and medium-sized enterprises, an increase in aggregate demand in the economy is ensured [13]. And the point is not so much in budget financing, but in off-budget investments, subsidies, subventions, loans.

Of course, the situation of the industry often depends on the region where it is located. Here, both the specifics of the climate and the availability of labor are important. It is important to understand that government support for business should balance the financial capabilities of all regions. Such an inter-regional redistribution was characteristic of the post-war period in Italy [16]. The measures necessary to support the economy can be both long-term [2], and urgent, caused by emergency. Those events that occur in the world today must be considered taking into account the experience of past economic crises. But at the same time, one cannot ignore the fact that modern world economic crises have peculiarities. These features are manifested in their causes, not only financial, political, economic or demographic. In recent years, the modern world has undergone tangible disasters, caused not only by globalization processes, but also by environmental disasters.

The research and analysis of factors leading to global crises is not the purpose of writing this scientific article. Our aim is to analyze the legal regulation of the measures that the state has provided in support of small and medium-sized enterprises in the emergency situation that has arisen today. The problems caused by the pandemic are not only momentary in nature. The consequences of a viral attack on the world are long-term and the likelihood that many entrepreneurs will not return to duty is quite high. Only about 5 months a new virus spreads all over the world, but the events following it pose a real menace to the relationships that exist in society [15].

\section{Methodology}

The research was conducted on the basis of general scientific methods of cognition. The systematic approach made it possible to generalize the existing problems in the legal regulation of small and medium-sized businesses. The comparative method made it possible to find common and identify individual problems in the legal regulation of state support for business in different countries.

The study of a large amount of material made it possible to draw a conclusion about the possible forecasting of economic crises caused by various reasons. An analysis of the legislative framework made it possible to hypothesize the advisability of developing legal norms providing for measures of state support for business in crisis periods "for the future" [17]. 


\section{Results}

The author of the well-known theory of the "Black Swan" Nassim Taleb in his work "On the Secrets of Sustainability" says that excessive globalization and interdependence, whether it is biological, cultural or economic, is alien to mother nature. The idea expressed by him is that a person is not able to prevent plagues and epidemics. Errors and accidents will always be present, despite the construction of various forecast models. It is necessary, following the laws of mother nature, to prevent the possible spread of these mistakes and fortuities throughout the system, isolate them in small zones [23].

Covid-19 overtaking the world turns its gaze to this theory and makes us think about the possible forecasting of such events. Crisis predictability was discussed after the global financial crisis in 2008. Due to the presence of clearly identifiable signs in this crisis, it was recognized as an extreme, but quite predictable event. Regardless of the name of the virus, the consequence of which was the concept of economic "sudden stop", it is necessary to develop emergency measures to contain it [5].

The financial and economic crises following the coronavirus pandemic indicate the necessity of serious lessons for all countries [12]. Was it possible to predict a situation that entailed the need for radical measures such as closing state borders, shutting down enterprises, stopping communication between countries, restricting freedom of movement of citizens? The answer to this question will most likely be positive.

Accordingly, it was necessary to be ready for such situations in advance: at the legislative level, develop state measures to support the population and business, create special funds, the funds from which can be used to support citizens and businesses. Clear rules and regulations governing the actions of authorities at all levels, legal entities, and citizens during the arrival of the "black swan", enshrined at the legislative level, would eliminate the need to create them in a hurry and contradict constitutional norms. What measures are being taken in states to prevent the economic consequences of a pandemic? The European Union has allocated 37 billion euros to protect the economies of the block. Of these, 8 billion euros to enterprises and companies that may suffer significant losses. The European Commission allowed the block countries to take loans without restrictions to help business.

In Germany, a package of measures has been adopted to assist private entrepreneurs and companies that could be significantly affected by the pandemic. The total amount of state support will be 750 billion euros. Small firms and private entrepreneurs are able to receive direct subsidies of up to 15 thousand euros, 50 billion euros have been allocated for this purpose. Hospitals will receive 3 billion euros, in all, Germany will spend up to $37 \%$ of the country's GDP on the fight against the pandemic.

The Ministry of Finance of England will provide companies with loan guarantees of 330 billion pounds, which is about $15 \%$ of the country's GDP, while interest can be paid for 6 months. Small enterprises are exempted from paying business tax for the duration of the epidemic. The Italian Council of Ministers has allocated 25 billion euros to support families and companies in emergency situations. Payments on loans and credits to businesses and households are suspended under state guarantees for banks. In total, 10 billion euros have been reserved for supporting families and entrepreneurs. 
The Spanish government has allocated 200 billion euros or $20 \%$ of the country's budget to combat the pandemic and its consequences. Of these, 117 billion euros are public funds, the rest is private resources. 100 billion are presented in the form of state loan guarantees. The Polish government has allocated 46.2 billion euros. Part of this money will be provided to entrepreneurs. In addition, credit guarantees, microloans, and operating leasing are provided. For companies that will not lay off employees, the state will cover $40 \%$ of the payroll. 1.6 billion has been allocated for healthcare. In the United States, the law "On the provision of financial assistance to casualties of the epidemic" allocated \$ 100 billion. The Senate approved a package of measures stimulating the economy in the amount of 2 trillion. dollars, in particular, 500 billion dollars. transferred to the support fund for enterprises, cities, and states, of which 25 billion to airlines, 17 billion to strategically important companies. The government will pay 500 billion dollars to Americans with incomes up to 75 thousand a year $-\$ 1,200$ per adult and \$ 500 each. per child. To support small businesses for measures on tax holidays allocated 350 billion dollars. In France, the enterprises that suffered losses were allocated 45 billion euros. Of the same amount, benefits are paid to employees who are transferred to the partially unemployed regime. A state guarantee was provided for bank loans of the enterprise in the amount of 300 billion euros. Small businesses will receive assistance in the amount of 1,500 billion euros. €500billion has been allocated for airlines that incurred losses.

In the world, the main measures taken in support of small and medium-sized businesses are to provide tax and credit holidays, lower interest rates on loans and income taxes, up to full exemption for an emergency, and direct cash support. It is the expediency of measures in the form of direct cash injections, both in business and provided to citizens, that causes the most controversy. The negative impact on the economic efficiency of investments and scientific and technological innovations was expressed even before the pandemic [16]. In the current situation in Russia, the possibility of direct cash assistance to both citizens and businesses finds opponents. The measures chosen by each country depend not only on the economic structure, but also on domestic opportunities. According to many economists, the difficult situation in Russia, caused by the decline in oil prices and the depreciation of the ruble, does not allow "distributing" money to citizens, as in America. For the rest, Russia takes actions similar to those of other states - introduces tax and credit benefits, provides a lease on the lease of municipal and state property for business, and exempts from a number of mandatory contributions until the end of the year.

\section{Discussion}

What measures and for whom were developed in Russia in the context of the spread of coronavirus to save business?

The measures taken by the Russian Federation are aimed at supporting small and medium-sized enterprises, which, in the opinion of the government, have fallen into a difficult economic situation. The list of such sectors of the economy is approved by Resolution of the Government of the Russian Federation of 03.04.2020 N 434 [18]. Currently, this list is not closed, it is periodically updated. 
In April 2020, in the Russian Federation in the direction of economic support for small and medium-sized enterprises, federal laws were adopted, resolutions of the Government of the Russian Federation were issued, numerous letters were published, information was posted. As support measures, the government provides for credit benefits, tax and rental holidays, and a moratorium on bankruptcy.

Of the laws, it is necessary to name the Federal Law of 01.04.2020 N 103 "On Amendments to the Federal Law" "On the Suspension of Certain Provisions of the Budget Code of the Russian Federation and the Establishment of Specific Features of the Execution of the Federal Budget in 2020" [6], Federal Law of 03.04.2020 N 106 "On Amendments to the Federal Law" On the Central Bank of the Russian Federation (Bank of Russia) "and certain legislative acts of the Russian Federation regarding the peculiarities of changing the terms of a loan agreement" [7], Federal Law of April 22, 2020 N 121 "On Amendments to Part Two of the Tax Code of the Russian Federation" [8], Federal Law of April 1, 2020 N 98 "On Amendments to Certain Legislative Acts of the Russian Federation Regarding Emergency Prevention and Response" [9].

A number of government regulations is aimed at supporting the economy. Resolution of the Government of the Russian Federation of 02.04.2020 N 422 approved the "Rules for the provision of subsidies from the federal budget to Russian credit organizations for the reimbursement of shortfalls in their income on loans issued to legal entities and individual entrepreneurs in 2020 for urgent needs to support and maintain employment" [19], Resolution of the Government of the Russian Federation of 04.04.2020 N 466 approved the "Rules for the provision in 2020 from the federal budget of subsidies to Russian air transport organizations for reimbursement of expenses incurred the implementation of measures for the removal of citizens from foreign countries in which there is an unfavorable situation associated with the spread of a new coronavirus infection" [20].

The forced speed of adoption of regulatory legal acts has led to the need to supplement and clarify them with all kinds of letters, information, instructions. The adoption of such serious regulatory documents in a hurry led to the difficulty of their enforcement. Clarifications of the relevant departments, as well as of the Supreme Court of the Russian Federation were required to clarify the concepts introduced by the new laws and decrees. The concept regarding which there is a need for clarification includes, for example, the term "non-working day". Decree of the President of the Russian Federation of March 25, 2020 N 206 "On the announcement of non-working days in the Russian Federation" [3], introduced a new concept that does not apply to a "day off" or to a "holiday". The introduction of the new term caused a number of difficulties, such as payroll, granting leave and dismissal during the "non-working" days. In the aspect of labor relations, clarifications were given by the Ministry of Labor [10], and the meaning that he put into the new term radically differed from the meaning given to the concept of "non-working days" by labor legislation.

An assessment of the term in the civil law sense was given by the "Review of Certain Judicial Practice Issues Related to the Application of Legislation and Measures to Counteract the Spread of the New Coronavirus Infection (COVID-19) No. 1 on April 21, 2020", approved by the Presidium of the Supreme Court of the Russian Federation [21]. According to the Presidium, these days cannot be considered non-working in the sense that gives this concept to the Civil Code of the Russian Federation. Accordingly, 
they are not grounds for postponement of the fulfillment of obligations under Article 193 of the Russian Civil Code [2].

Many questions raise such a concept, used in regional restrictive acts, such as "high alert mode", expressions "temporarily suspend", "restrict". Firstly, they are not defined by law, and secondly, they do not allow the use of civil law to terminate obligations. Economic crisis is not only financial difficulties, unemployment and impoverishment of the population. It is also a manifestation of cruelty and violence, the criminalization of society. Studies have confirmed an increase in domestic violence from the economic downturn [22], and the experience of the crisis caused by the pandemic has shown an increase in the number of cases of child abuse [11]. Overcoming global crises should occur in interaction and mutual assistance, outside national interests. It is unacceptable, hiding behind the fight against the crisis, to forget about respect for human rights, justice and equality [25].

\section{Conclusion}

The number of risks that can cause global disasters is only increasing. Whether it is a problem with refugees, cyberattacks, environmental disasters or epidemics, all this affects the economic situation. The world is not always ready for these risks. In addition, factors that threaten our security are often related to each other and reinforce each other. The danger of events lies in their destructive distribution, as our world is interpenetrated, permeated by common networks [14]. It is this problem that mankind faced in the case of coronavirus. Such events should be predicted, and governments and businesses should be prepared for such events.

Small and medium-sized enterprises are included in the economic system of any country. Research on the identification of factors that have an effective impact on their work is given great importance [4]. The most important factors affecting the development of this sector of the economy and identified as a result of the study include government regulation and business support, which are based on a clear and understandable legal framework. Not all states can boast of such, so, according to entrepreneurs from the Czech and Slovak Republics, the level of legislation governing business and its state support is not very high [1]. The need for the functioning and development of small and medium-sized enterprises in accordance with laws and regulations, the solution to the problem of financing them on the basis of laws and regulations, say Chinese entrepreneurs [24].

It is necessary to improve the legal standards governing the support of small and medium-sized enterprises, providing for their effect, both in the normal course of events and in emergency situations. This will provide an opportunity to save time for solving super-urgent tasks in the event of a disaster. In addition, it will be possible to avoid those errors that usually arise during hasty rulemaking. Poor legal regulation leads to problems of law enforcement, free interpretation of legal norms and, accordingly, corruption loopholes. The ambiguity of the proclaimed norms often leads to the fact that they remain declared, but not enforceable. Small and medium-sized businesses always need state support, in a crisis situation, especially. The development of state 
measures to support entrepreneurs, based on a clear regulatory framework, is the only guarantee of their viability.

\section{References}

1. Cepel, M., Belas, J., Dvorsky, J.: The impact of significant political factors on starting a new business. In: Liargovas, P., (ed.) Proceedings of the European Conference on Innovation and Entrepreneurship, ECIE, pp. 220-228. Sonning Common: Academic Conferences and Publishing International Limited Reading (2019)

2. The Civil Code of the Russian Federation (book 1). "Meeting of the legislation of the Russian Federation", 05.12.1994, N 32, Art. 3301 (1994). http://www.consultant.ru/ document/cons_doc_LAW_5142/. Accessed 15 Apr 2020

3. Decree of the President of the Russian Federation of March 25, 2020 N 206 "On the announcement of non-working days in the Russian Federation" (2020). https://base.garant. ru/73793643/. Accessed 20 Apr 2020

4. Elver, H.: New constitutionalism and the environment. In: Gill, S., Cutler, A.C. (eds.) New Constitutionalism and World Order, pp. 261-276. Cambridge University Press, Cambridge (2012)

5. Faggini, M., Bruno, B., Parziale, A.: Crises in economic complex networks: black swans or dragon kings? Econ. Anal. Policy 62, 105-115 (2019)

6. The Federal Law of 01.04.2020 N 103 "On amendments to the Federal Law "On the suspension of certain provisions of the budget code of the Russian Federation and the establishment of specific features of the execution of the federal budget in 2020" (2020). http://www.consultant.ru/document/cons_doc_LAW_349085/. Accessed 15 Apr 2020

7. The Federal Law of 03.04.2020 N 106 "On amendments to the Federal Law" On the central bank of the Russian Federation (Bank of Russia) "and certain legislative acts of the Russian Federation regarding the peculiarities of changing the terms of a loan agreement" (2020). http://base.garant.ru/73842090/. Accessed 15 Apr 2020

8. The Federal Law of April 22, $2020 \mathrm{~N} 121$ "On amendments to part two of the tax code of the Russian Federation" (2020). http://base.garant.ru/73929695/. Accessed 15 Apr 2020

9. The Federal Law of April 1, $2020 \mathrm{~N} 98$ "On amendments to certain legislative acts of the Russian Federation regarding emergency prevention and response" (2020). https://base. garant.ru/73828134/. Accessed 15 Apr 2020

10. Information of the ministry of labor and social protection of the Russian Federation of April 2, 2020 "Questions and answers on the organization of work and respect for the rights of workers during the non-working week" (2020). https://www.garant.ru/products/ipo/prime/ doc/73734356/. Accessed 15 Apr 2020

11. John, N., Casey, S.E., Carino, G., McGovern, T.: Lessons never learned: crisis and genderbased violence (2020). https://onlinelibrary.wiley.com/doi/abs/10.1111/dewb.12261. Accessed 15 Apr 2020

12. Lucchese, M., Pianta, M.: The coming coronavirus crisis: what can we learn? Intereconomics 55(2), 98-104 (2020)

13. Makrelov, K., Arndt, C., Davies, R., Harris, L.: Balance sheet changes and the impact of financial sector risk-taking on fiscal multipliers. Econ. Model. 87, 322-343 (2020)

14. Masys, A.J.: Complexity and security: new ways of thinking and seeing. In: Masys, A.J., Lin, L.S.F., (eds) Asia-Pacific Security Challenges. Advanced Sciences and Technologies for Security Applications, pp. 1-17. Springer, Cham (2018) 
15. McCullough, P.A., Eidt, J., Rangaswami, J., Lerma, E., Tumlin, J., Wheelan, K., Ronco, C.: Urgent need for individual mobile phone and institutional reporting of at home, hospitalized, and intensive care unit cases of SARS-CoV-2 (COVID-19) infection. Rev. Cardiovasc. Med. 21(1), 1-7 (2020)

16. Öncü, T.S.: Triggering a global financial crisis: COVID-19 as the last straw. Econ. Polit. Wkly. 55(11), 10-12 (2020)

17. Petraglia, C., Pierucci, E., Scalera, D.: Interregional redistribution and risk sharing through public budget. the case of Italy in times of crisis (2000-2016). Struct. Change Econ. Dyn. 53, 162-169 (2020)

18. Resolution of the Government of the Russian Federation of 03.04.2020 N 434 (Rev. 18.04.2020), "On approval of the list of branches of the Russian economy most affected by the worsening situation caused by the spread of new coronavirus infection" (2020). http:// www.consultant.ru/document/cons_doc_LAW_349344/. Accessed 15 Apr 2020

19. Resolution of the Government of the Russian Federation of 02.04.2020 N 422 (red. of 24.04.2020) "Rules for the provision of subsidies from the federal budget to Russian credit organizations for the reimbursement of shortfalls in their income on loans issued to legal entities and individual entrepreneurs in 2020 for urgent needs to support and maintain employment" (2020). https://www.garant.ru/products/ipo/prime/doc/73741776/. Accessed 16 Apr 2020

20. Resolution of the Government of the Russian Federation of 09.04.2020 N 466 "Rules for the provision in 2020 from the federal budget of subsidies to Russian air transport organizations for reimbursement of expenses incurred the implementation of measures for the removal of citizens from foreign countries in which there is an unfavorable situation associated with the spread of a new coronavirus infection" (2020). http://www.consultant.ru/document/cons_ doc_LAW_349996/. Accessed 19 Apr 2020

21. Review of certain judicial practice issues related to the application of legislation and measures to counteract the spread of the new coronavirus infection (COVID-19) No. 1 on April 21, 2020 (approved by the Presidium of the supreme court of the Russian Federation) (2020). https://www.vsrf.ru/press_center/news/28855/. Accessed 15 Apr 2020

22. Schenck-Fontaine, A., Gassman-Pines, A.: Income inequality and child maltreatment risk during economic recession. Child. Youth Serv. Rev. 112(C) (2020). https://ideas.repec.org/a/ eee/cysrev/v112y2020ics019074091931014x.html. Accessed 15 Apr 2020

23. Taleb, N.: On the secrets of sustainability. In: Tyunkina, M., (ed.) The Black Swan. The Impact of the Highly Improbable, pp. 212-246. KoLibry, Moscow (2007)

24. Xi, W.: The modeling and simulation of the cloud financing model for technology-based small and medium-sized enterprises. In: Abawajy, J.H., Choo, K.-K.R., Islam, R., Xu, Z., Atiquzzaman, M., (eds) International Conference on Applications and Techniques in Cyber Intelligence ATCI 2019. Aplications and Techniques in Cyber Intelligence, vol. 1017, pp. 1057-1062. Springer, Cham (2020)

25. Xuan, V.N., Thu, N.T.P., Anh, N.T.: Factors affecting the business performance of enterprises: evidence at Vietnam small and medium-sized enterprises. Manage. Sci. Lett. 10 (4), 865-870 (2020) 